\title{
Entre a disputa e a coprodução: a imagem do Exército Brasileiro no Complexo da Maré
}

Between the dispute and the co-production: the image of the Brazilian Army in the Complexo da Maré

Entre la disputa y la coproducción: la imagen del Ejército Brasilero en el Complexo da Maré

Ana Paula da Rosa

- Doutora em Ciências da Comunicação pela Universidade do Vale do Rio dos Sinos (Unisinos)

- Mestre em Comunicação e Linguagens pela Universidade Tuiuti do Paraná (UTP)

- Graduada em Jornalismo pela Universidade de Passo Fundo (UPF)

- Docente e pesquisadora no PPG em Ciências da Comunicação da Unisinos, na linha de pesquisa Midiatização e Processos Sociais

- Atuou como professora na Universidade Tecnológica Federal do Paraná (UTFPR) e na Universidade Federal do Paraná (UFPR)

- Foi coordenadora de graduação nas áreas de Publicidade, Jornalismo, Rádio e TV e Marketing na UTP

- E-mail:anaros@unisinos.br

\section{Bruno Garcia Vinhola}

- Mestre em Ciências da Comunicação pela Universidade do Vale do Rio dos Sinos (Unisinos)

- Especialista em Planejamento da Comunicação e Gestão de Crises pela Pontifícia Universidade Católica do Rio Grande do Sul (PUC-RS)

- Graduado em Jornalismo pelo Centro Universitário Metodista IPA, de Porto Alegre

- E-mail: brunovinhola@hotmail.com 


\section{Resumo}

Entre 2014 e 2015, as Forças Armadas estiveram envolvidas na operação de pacificação do Complexo da Maré, no Rio de Janeiro. Tal acontecimento configura uma atmosfera tensional que oferece condições para um embate por produção de sentido. De um lado, a instituição não midiática Exército, de outro, as instituições jornalísticas, produzindo discursos e imagens sobre o fato. No entanto, um terceiro elemento agrega-se a esta paisagem circulatória, os atores sociais, que também passam a produzir e elaborar a pacificação nos dispositivos midiáticos a que têm acesso. Partindo dos conceitos de midiatização e circulação, tem-se aí configurada uma disputa. Assim, investiga-se o processo de construção da imagem do Exército durante a operação, com base nas materialidades coletadas referentes ao período da ocupação do Complexo da Maré. Ao final, a correlação desses indícios revela elementos além da disputa, o que torna ainda mais complexa a circulação imagética midiatizada.

\section{PALAVRAS-CHAVE: MIDIATIZAÇÃO • CIRCULAÇÃO • IMAGEM • EXÉRCITO BRASILEIRO.}

\section{Abstract}

During 2014 and 2015 the Armed Forces were involved in the operation of pacification of the Complexo da Maréshantytown, in Rio de Janeiro. This event establishes a tense atmosphere that offers conditions for a dispute for production of meaning. On the one side, the Army, a non-mediatic institution; on the other the journalism institutions, producing discourses on and images of the fact. However, a third element is aggregated with this circulating scenery, the social actors, who also begin to produce and develop the pacification in the mediatic aspects to which they have access. Based on the concepts of mediatization and circulation, one has a configured dispute. Thus, one investigates the process of construction of the image of the Army during the operation, based on the gathered materiality relative to the period of occupation of the Complexo da Maré. Finally, the correlation of these evidences reveals elements that go beyond the dispute, which causes the circulation of mediatized imagism.

\section{Resumen}

Entre 2014 y 2015, las Fuerzas Armadas participaron en la operación de pacificación del complejo habitacional "da Maré", en Río de Janeiro. Tal acontecimiento configura una atmósfera de tensión que ofrece las condiciones para un enfrentamiento por la producción de sentido. Por un lado, la institución no mediática Ejército, del otro, las instituciones periodísticas en la producción de discursos e imágenes sobre el hecho. Sin embargo, un tercer elemento se suma a este paisaje circulatorio, los actores sociales, que también comienzan a producir y elaborar contenidos sobre la pacificación en dispositivos mediáticos a los que tienen acceso. A partir de los conceptos de mediatización y circulación, allí tiene configurada una disputa. Así, se investiga el proceso de construcción de la imagen del Ejército durante la operación, con base a las materialidades colectadas referentes al período de ocupación complejo habitacional. Por último, la correlación de estos indicios revela elementos más allá de la disputa, lo que hace aún más compleja la circulación imagética mediatizada. 


\section{ANO 13 • NÚMERO 24 • 1은. 2016 • ORGANICOM \\ ENTRE A DISPUTA E A COPRODUÇÃO: A IMAGEM DO EXÉRCITO BRASILEIRO NO COMPLEXO DA MARÉ}

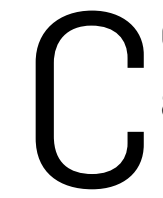

omo prelúdio, uma breve descrição do acontecimento. Rio de Janeiro, março de 2014. 0 governo estadual solicita apoio da Presidência da República para o emprego das Forças Armadas no Complexo da Maré, um conjunto de favelas localizado em uma região estratégica da cidade, historicamente conhecido pelo domínio do tráfico de drogas. Um decreto presidencial autoriza a atuação de tropas em ações de garantia da lei e da ordem e o Exército Brasileiro passa a comandar uma Força de Pacificação (FPac)', com o objetivo de reestabelecer a paz social na região da Maré.

A entrada dos militares no Complexo da Maré desperta a irrupção de um campo problemático. 0 acontecimento acarreta uma série de matrizes de interpretação, configurando uma atmosfera tensional que oferece as condições ideais para um embate por produção de sentido. Um dos elementos em disputa é o que provoca nossas indagações: a imagem do Exército Brasileiro. Questiona-se: como é construída a imagem da instituição durante a operação de pacificação das comunidades da Maré?

Para o entendimento de tal processo, faz-se necessário verificar primeiro quem é o responsável. Aquele que conta a história do que aconteceu na Maré e, consequentemente, afeta a imagem do Exército. Naturalmente, seria quem é capacitado a dar forma narrativa ao acontecimento, tornando-o midiático. Suporíamos então que cabe à instância da mídia canônica² a tarefa de registrar o fato bruto dentro das peculiaridades de seu sistema produtivo e, a partir daí, produzir sentido e imagens.

Mas, quando creditamos o poder da construção social da realidade exclusivamente à mídia canônica, estamos discutindo uma sociedade que já não existe mais. Chamamos de sociedade dos meios, das mídias ou midiática essa ambiência em que a mediação se encontrava restrita ao domínio da mídia canônica. 0 campo dos media ostentava autonomia ${ }^{3}$, à medida que figurava como a única instituição legitimada para permear, transpor ou se expandir entre as fronteiras dos campos sociais. Essa autonomia estava vinculada à natureza tecnossimbólica do campo dos media, que o fazia capaz de superintender as relações societárias. Afinal, ele pode falar de tudo, de uma forma acessível a todos. A sociedade respeitava as leis da instrumentalidade dos meios que, a partir dos agendamentos, das formações de opinião e da comunicação baseada no modelo linear de emissão-recepção, garantiam as estruturas do social em uma tarefa organizadora.

No entanto, se a tarefa de contar a história não está mais limitada ao midiático canônico, ela está dividida. Outros atores estão participando da narrativa do acontecimento e, consequentemente, da produção de sentido. É algo que modifica e torna ainda mais complexa a processualidade imagética4.

\section{RIVALIDADES INTERMIDIÁTICAS: A IMAGEM EM DISPUTA NA MIDIATIZAÇÃO}

Esses outros atores que participam da construção da imagem do Exército e do jogo social foram encontrados em meio às materialidades. Em um processo de ida e volta aos indícios, na tentativa de apreensão do que é efetivamente relevante,

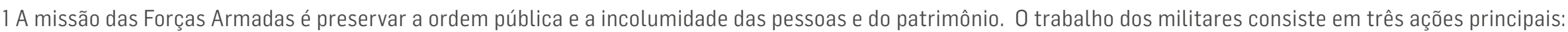

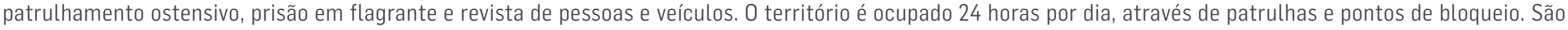
enviadas tropas de diferentes regiões do país, respeitando um sistema de rodízio.

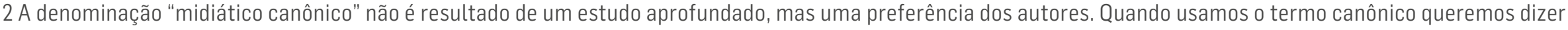

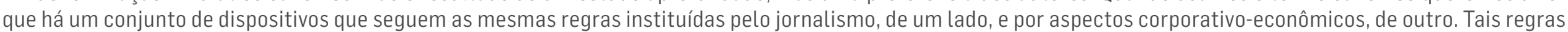

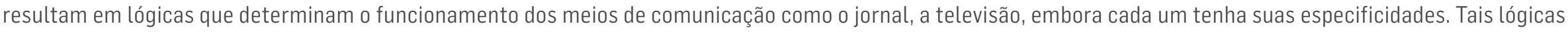
são estendidas para os sites destes veículos.

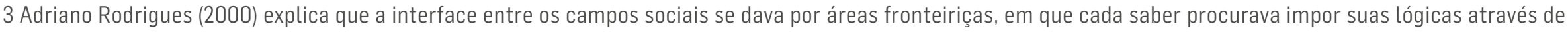
seus especialistas. Com a sociedade dos meios, o campo midiático se torna o grande articulador de relações.

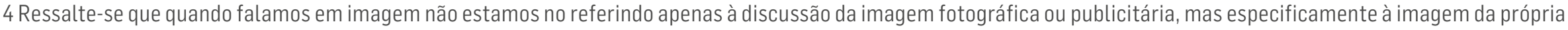

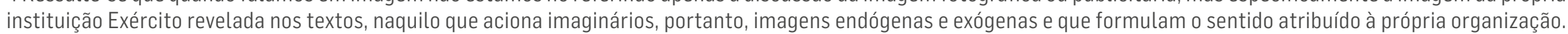


chegou-se a três esferas de análise, com base no esquema prógono de Eliseo Verón (1997, p. 14) para análise da midiatização. A coleção de indícios, dessa forma, conta com as materialidades produzidas pelas esferas do institucional, da mídia canônica e dos atores sociais midiatizados. Como o objetivo da coleta foi recuperar produtos circulantes nos dispositivos midiáticos, definiu-se como fonte de pesquisa os dispositivos encontrados na internet, pois a mesma se revela como um espaço em que todas as instâncias disputantes teriam condições similares de produção (em grande quantidade e sem disparidades relevantes que poderiam prejudicar o caráter abrangente da análise). 0 período de análise das materialidades diz respeito ao início da operação: produções inscritas nos dispositivos midiáticos entre os dias 2 e 10 de abril de 2014, poucos dias antes e depois da entrada dos militares na favela (5 de abril). A seguir, uma primeira sequência de imagens.

Figura 1

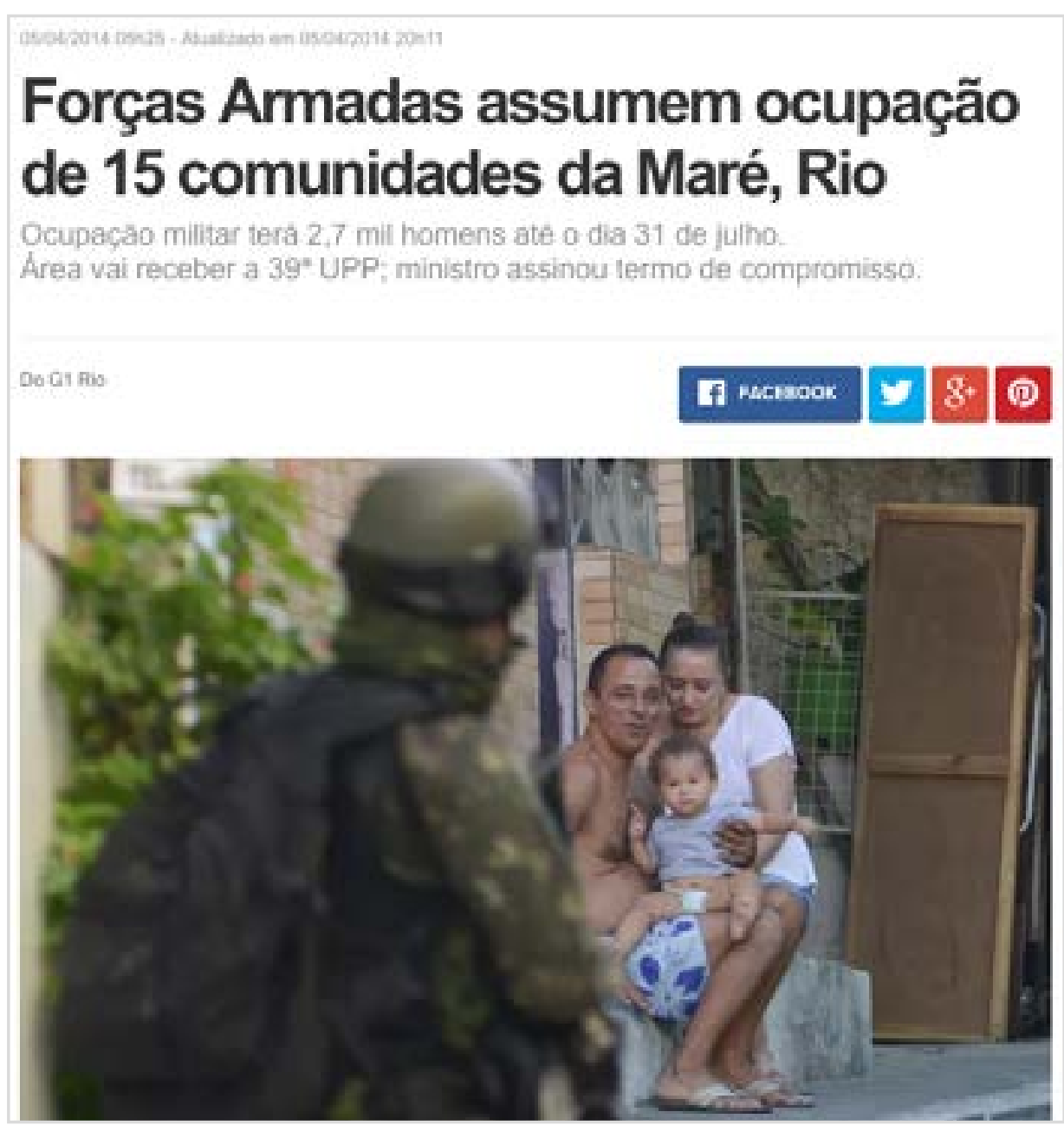

Fonte: http://g1.globo.com/rio-de-janeiro/noticia/2014/04/ forcasarmadas-assumem-ocupacao-de-15-comunidades-da-mare-rio.html.

Figura 2

\section{Forcas Armadas ocupam o Conjunto de Favelas da Maré. Ocupação è formalizada oficialmente}

Rio de Janeiro - As Forz̧as Armadas ocuparam, na manhâ de 5 de abril, o Conjunto de Favelas da Maré, na Zona Nonte do Rio de Janeiro, em substituição à Poticia Milltar. Aproximadamente 2.700 homens da Força de Pacificação entraram no complexo de comunidades, uma area de aproximadamente 10 quilómetros quadrados, dando inicio i. Operaç3o S3o Francisco.

O avanço das tropas foi concluido sem confrontos com as organizaçōes criminesas que atuam na reglào. A açào foi comandada pelo General Escoto, Comandante da Brigada de infantaria Paraquodista, que pessoalmente avaliou as condiçōes do local.

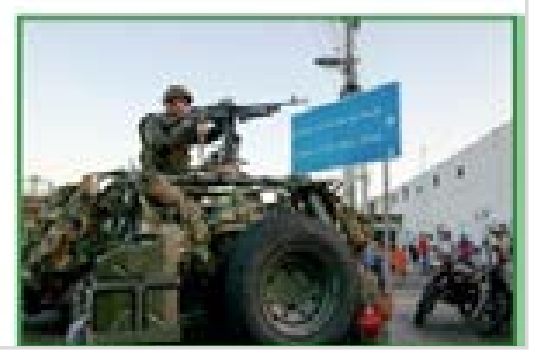

Fonte: http://www.eb.mil.br/web/midia-impressa/o-que-vai-pela-forca. 
Figura 3

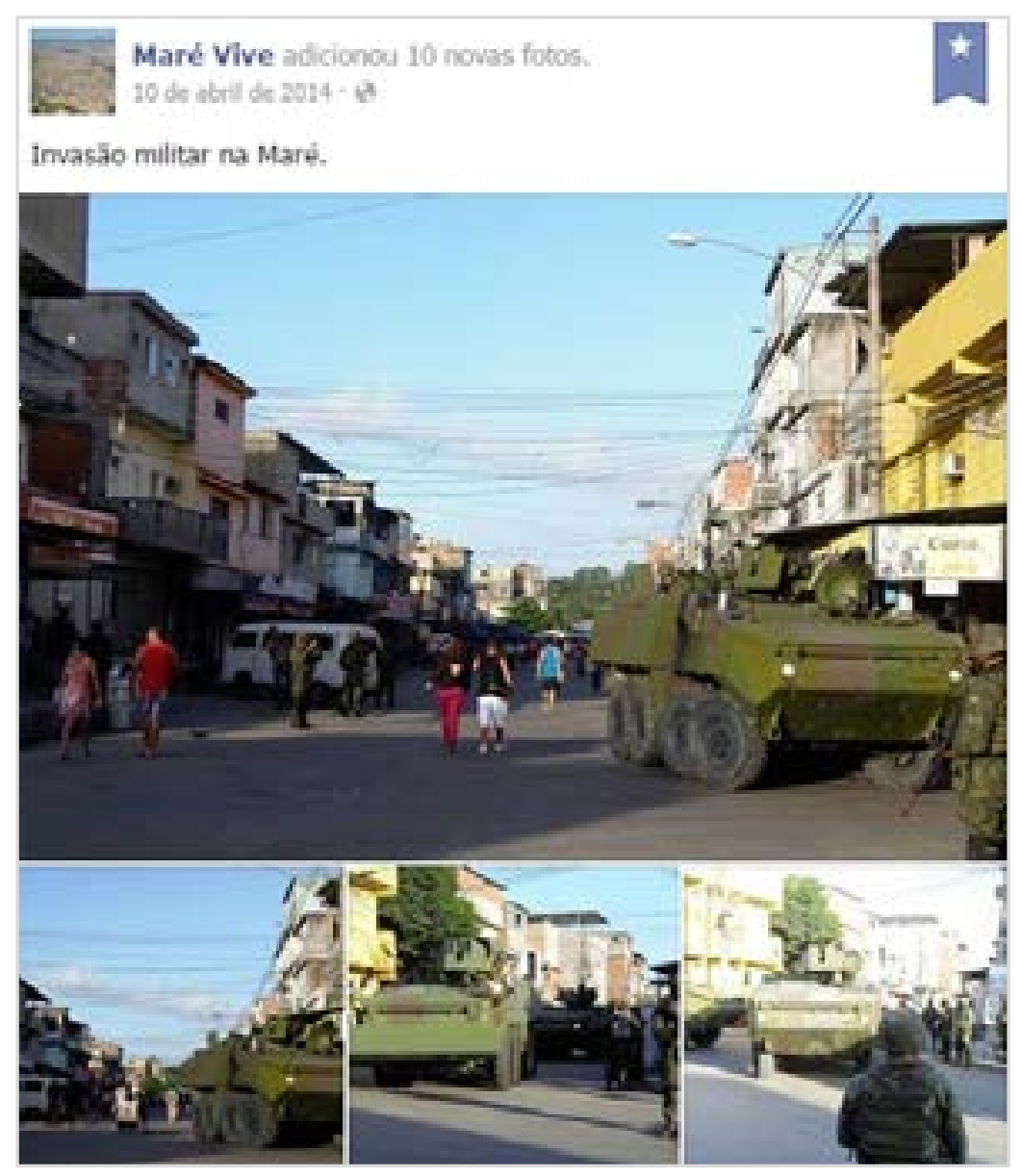

Fonte: https://pt-br.facebook.com/Marevive.

Na observação dessas imagens, percebemos três construções heterogêneas, processos efetuados através de dispositivos midiáticos, nas três instâncias que apresentamos acima. 0 primeiro registro é o da mídia canônica, enquadrado em um sistema produtivo jornalístico. A segunda imagem é produzida pela própria instituição não midiática ${ }^{5}$, colocada para circular em um dispositivo assinado também por ela (o portal oficial do Exército Brasileiro). E a terceira imagem é uma produção dos atores individuais, os usuários comuns/amadores, provavelmente moradores do território da Maré que estão presenciando o acontecimento e inscrevendo sua percepção da imagem do Exército em outros dispositivos. A partir da observação das três diferentes imagens do Exército em produção, infere-se que há em curso uma disputa intermidiática. A imagem do Exército está atravessada no terreno intermidiático, mobilizada por estratégias concorrentes de produção de sentido.

Analisemos outras imagens correspondentes a essas mesmas instâncias, a fim de desconstruirmos estratégias e entendermos os movimentos realizados pelos participantes dessa disputa, que lançam mão de suas formas de acesso ao midiático.

Figura 4

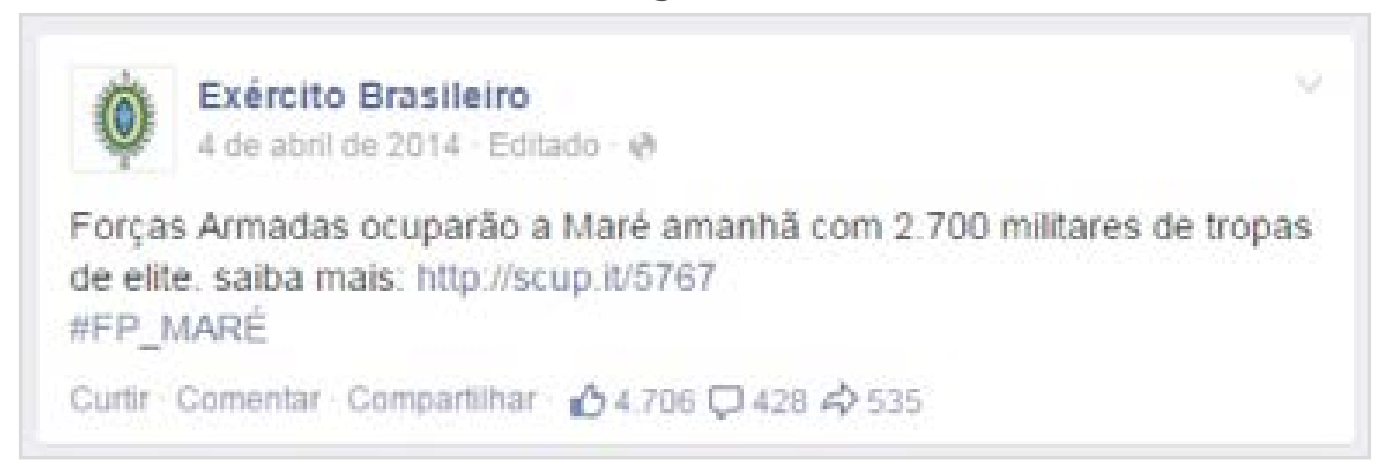

Fonte: https://pt-br.facebook.com/exercito/posts/852982138062049.

5 As expressões instituições midiáticas, não midiáticas e atores sociais são empregadas retomando o esquema de Verón (1997, p. 14), quando este se refere à circulação, mas adaptando-o. Este deslocamento integra pesquisa maior de Bruno Vinhola, orientada por Ana Rosa, no PPG em Ciências da Comunicação da Unisinos. 
Figura 5

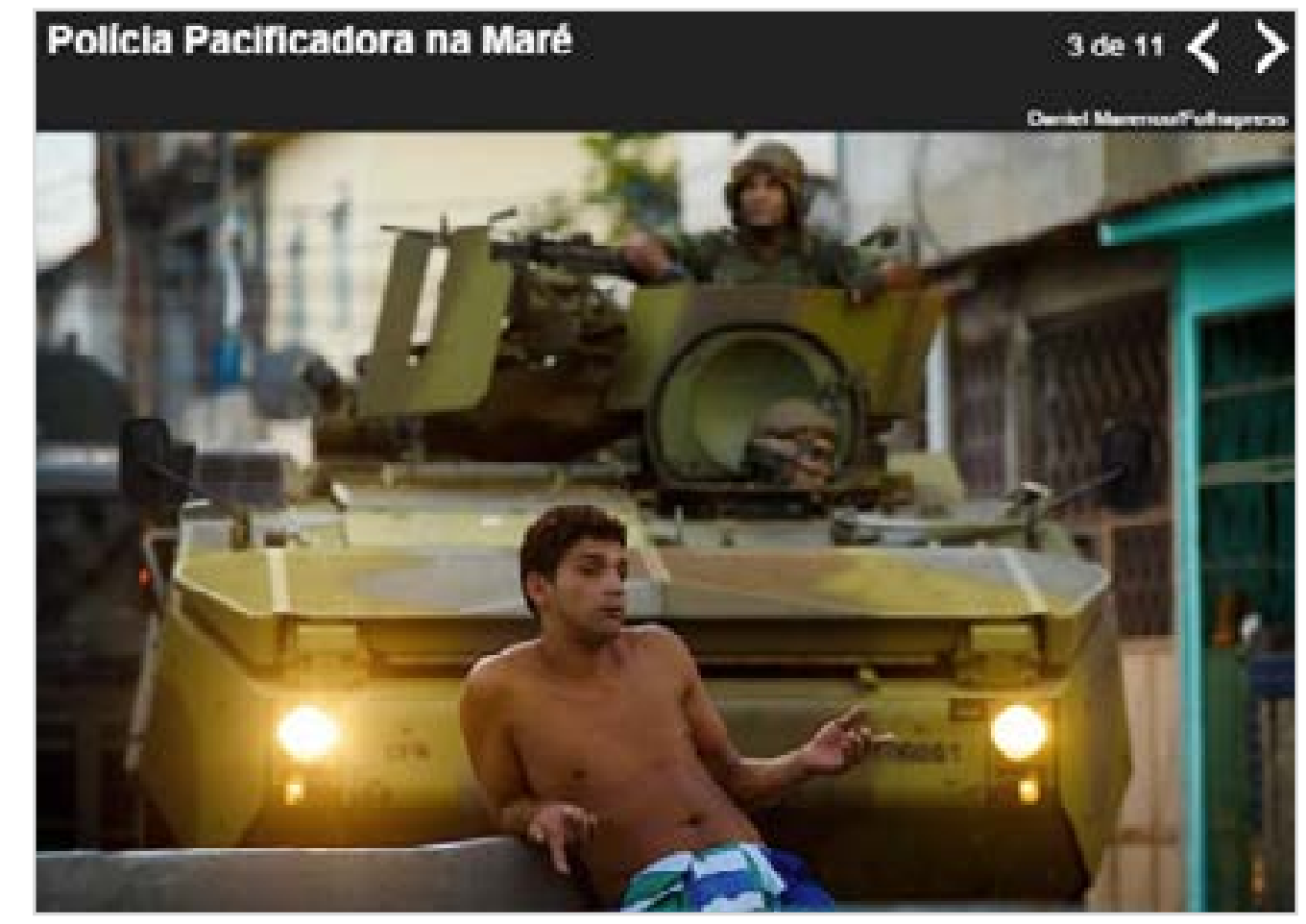

Fonte:http://www1.folha.uol.com.br/cotidiano/2014/04/1436381-forcasarmadas-iniciam-ocupacao-do-complexo-da-mare-no-rio.shtml.

Figura 6

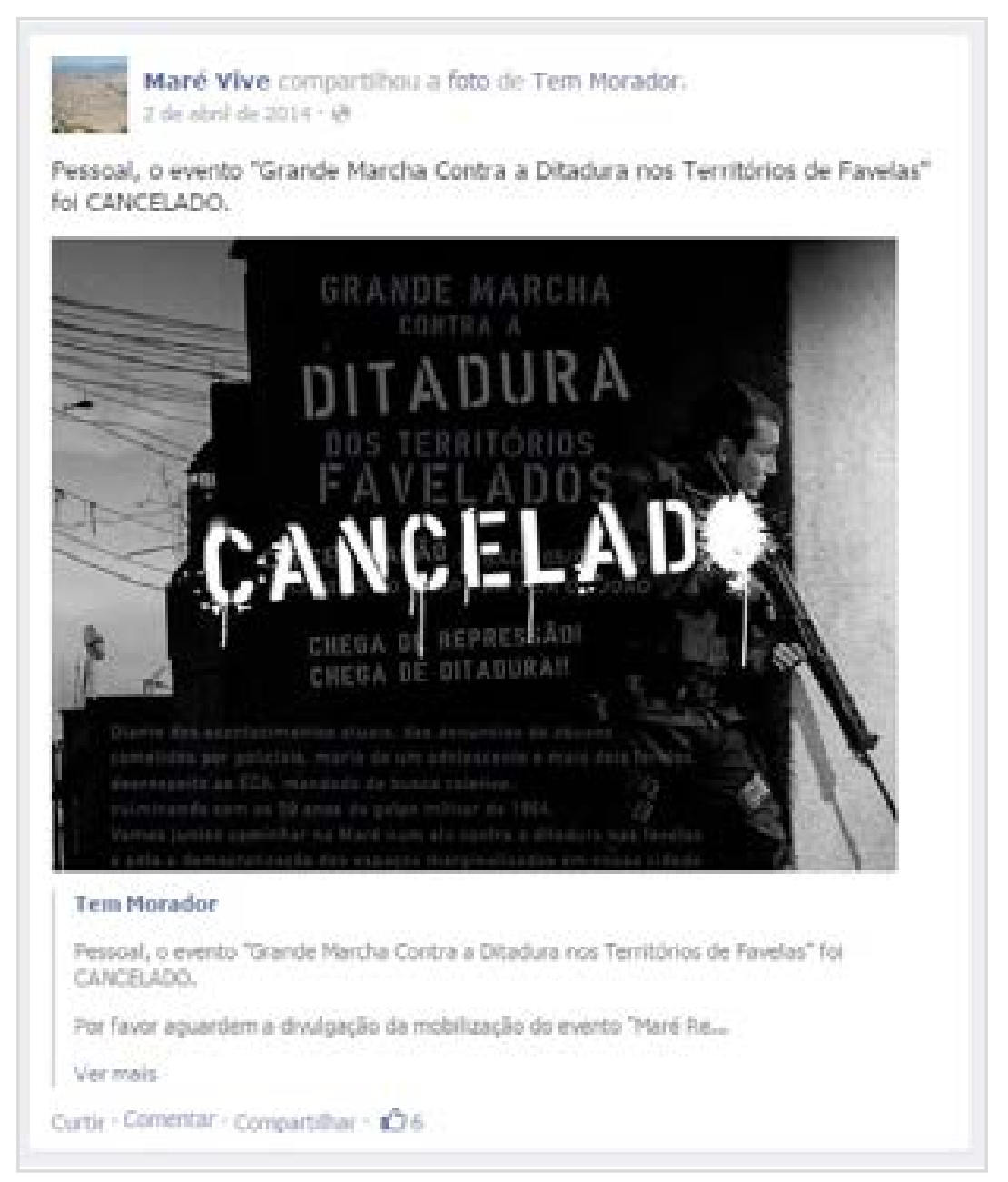

Fonte: https://pt-br.facebook.com/Marevive.

A figura 4 corresponde a uma postagem oficial da instituição Exército em sua fanpage no Facebook. Essa publicação reforça o sentido produzido pela matéria veiculada no portal do Exército (figura 2), de uma ocupação militar. E quanto à pacificação? Após a verificação dos conteúdos publicados nos dispositivos assinados oficialmente pela instituição, não foi encontrado 
o detalhamento do trabalho que seria realizado pelos militares dentro das comunidades. Sendo assim, nesta fase inicial de produção de sentido, não há referências da parte institucional do que viria a ser de fato a pacificação. Na figura 2 , observamos a valorização do número de militares e dos recursos empregados na operação, o que exalta o poder de combate a ser empregado. Tal sentido é ratificado pela fotografia do militar em seu blindado adentrando a favela. Ainda na mesma publicação, é notável a valorização da autoridade militar, quando lemos que o primeiro comandante da Força de Pacificação "pessoalmente avaliou as condições do local" ao comandar a ação. Na figura 4, novamente podemos verificar a exaltação do poder da tropa que atuará na Maré, tanto em número como em capacidade profissional.

As imagens das figuras 1 e 5 enquadram-se no sistema produtivo jornalístico. Na figura 1, assim como ocorre no âmbito institucional, a ideia de uma ocupação militar logo começa a ser formada. Nessa fotografia tem-se um militar patrulhando as estreitas vias da favela prestes a encarar uma família de moradores. Entre eles, um hiato duvidoso: 0 militar parece se deslocar cautelosamente, enquanto os moradores revelam um composto de reações. Receio, desconfiança, medo. Em expressões diferentes, as três pessoas emanam seu estranhamento para com a Força. Embora não esteja plenamente visível na imagem, o ângulo da foto evidencia o soldado em primeiro plano com a arma em punho em direção à família, que, em foco na cena, demonstra estar acuada. Olhamos a imagem como quem adentra a favela, literalmente a invade, 0 espectador é representado pelo fotógrafo que também "captura" a família, sua intimidade, seu cotidiano. Há aí um misto de força, com a noção de estar de indefeso, contrariando o que se esperaria da operação.

Na figura 5, a imposição da força bruta por parte do Exército é apresentada de maneira mais direta. Na imagem fotográfica, a viatura militar parece disposta a atravessar tudo o que está na frente. 0 estranhamento dos habitantes do Complexo da Maré também é explorado de modo mais intenso. Dessa vez, ele vem acompanhado da dúvida, afinal o morador parece estar perguntando o porquê de o Exército estar ali. Uma espécie de deboche, um princípio de oposição. Obviamente percebe-se que não se trata de uma imagem naturalizada, mas de uma imagem marcada pela pose. 0 homem que está recostado ao muro certamente foi orientado antes do registro, mas, independentemente disso, a fotografia gera um efeito de sentido, que novamente insinua uma contradição com o título da galeria de imagens "Polícia pacificadora na Maré". A instância da mídia canônica, ao combinar a ocupação do território pela força com o estranhamento e a dúvida dos locais, produz uma imagem muito mais próxima da tensão do que da pacificação. 0 valor-notícia parece ser o choque que a ocupação militar causa na população. Por fim, uma característica comum às duas imagens: o resgate de um passado opressor vinculado à imagem do Exército. As figuras 1 e 5 em muito lembram as imagens do período do Regime Militar no Brasil. Blindados atravessando as ruas, militares fortemente equipados, cidadãos com expressões de medo ou desconfiança. Imagens de um Exército que amedronta e que se impõe pela força. Uma espécie de imagem contaminada, que traz elementos histórico/ sociais enraizados na cultura, e que agora é recuperada.

Por fim, a produção dos atores sociais. As figuras 3 e 6 são construções consideradas amadoras, conteúdos postos a circular por indivíduos comuns, mas que se autonomizam em redes sociais. A primeira imagem não só rompe com o sentido da pacificação, como assume de maneira clara uma postura oposicionista à ação do Exército no Complexo da Maré. A ocupação se torna uma invasão militar. Evidencia-se 0 aparato militar modificando a paisagem natural da comunidade. Os atores sociais, através das redes e páginas colaborativas, fazem a dúvida sobre a operação se espalhar em circuitos diversos, agora com 0 acréscimo da revolta. Embora se perceba uma inter-relação dos critérios de registro dos fatos da mídia canônica, pois as imagens são parecidas com as publicações jornalísticas, os amadores têm o poder de explicitar um sentido que 0 canônico não tem, devido às restrições de seu sistema produtivo. Na figura 6, a revolta se transforma em campanha: deboche, ironia, difamação, excessos de vários tipos contra os militares são expostos em uma verdadeira convocação popular para a resistência contra a "ditadura dos territórios favelados". 
A partir da observação desse material heterogêneo produzido por cada uma dessas instâncias que coabitam o terreno intermidiático, é reforçada a ideia de que há uma disputa pela construção da imagem do Exército durante a pacificação do Complexo da Maré. A esfera institucional procurou defender o sucesso da operação, exaltar a figura do militar e do Exército e valorizar seu poderio bélico, resultando no que classificamos como a imagem de um Exército do valor. Já na instância da mídia canônica, observamos a tentativa do resgate de um passado opressor do Exército, junto da desmistificação e exposição de vulnerabilidades da figura do militar, combinados ao questionamento acerca do sucesso da operação; inferimos que aí se cria a imagem de um Exército da dúvida. E por último, no âmbito dos atores sociais, uma campanha direta contra a atuação dos militares, com a total desvalorização da instituição; a opressão velada da mídia canônica é reforçada e vai mais além, produzindo a imagem de um Exército do medo.

Considerando que está em curso a produção de três diferentes imagens da mesma instituição, retoma-se a pergunta sobre quem está contando a história da pacificação na Maré. A partir das materialidades indiciadas, nota-se que outros atores se credenciam como potenciais narradores. Quando as instâncias da mídia canônica, do institucional e dos atores sociais inscrevem seus discursos para circular em condições de igualdade, é sinal de que aquela sociedade em que a mediação estava sob responsabilidade exclusiva dos meios não é mais a realidade que vivemos. A mídia canônica perde sua centralidade, 0 que reconfigura as relações na matriz societária. Estamos, enfim, entrando na sociedade em midiatização.

Na tentativa de sintetizar o conceito de midiatização procurou-se articular fragmentos das perspectivas dos autores que discutem o conceito. Partindo das ideias do esquema de Verón (1997, p. 14) para análise da midiatização, trabalhamos 0 fenômeno adotando a perspectiva de mutação qualitativa dos processos de câmbio social, e não de acumulação quantitativa de novas mídias. Elencamos então quatro características da processualidade: a midiatização é caracterizada pela expansão e instauração acelerada na sociedade de fenômenos técnicos transformados em meios (Fausto Neto, 2008, p. 91). Isso altera os processos interacionais e a construção do real, fazendo-os funcionar sob as lógicas de mídia (Braga, 2006, p. 1), através de articulações entre dispositivos midiáticos, processos sociais e processo de comunicação que incidem sobre a produção de sentido (Ferreira, 2007, p. 2), resultando em um salto qualitativo alcançado por essa nova ambiência, caracterizada pelo compartilhamento de experiências em um verdadeiro caldo cultural (Gomes, 2013, p. 137).

Para explicar o atravessamento dessas características em nosso caso, comecemos pelos fenômenos técnicos transformados em meios. Assim como Verón, Antonio Fausto Neto (2008, p. 91) enxerga a midiatização para além do determinismo tecnológico. 0 argumento é que as tecnologias se espalham por toda a sociedade segundo algumas lógicas de ofertas e usos. Tais lógicas podem levar a apropriações; no entanto, neste caso elas estão sujeitas a desvios e transformações pela ação do próprio homem. Dessa forma, os fenômenos técnicos emergiram e foram transformados em meios, gerando novas formas de interação e repercutindo na vida e na organização da sociedade. A reconfiguração das invenções tecnológicas a partir das práticas sociais criou condições para que todos os campos sociais fizessem uso e pudessem se apropriar das tecnologias, convertendo-as em meios. Por outro lado, os meios de comunicação perdem o poder de controle que tinham sobre a mediação e, consequentemente, sobre as estruturas da sociedade. Esse poder passa a ser partilhado ou difuso. É claro que ainda enxergamos modos de expressão do poder do midiático canônico, mas já não se trata da única forma de poder. Como foi exposto nas materialidades acima, as técnicas midiáticas, antes dominadas apenas pela mídia canônica, agora estão à disposição dos atores sociais e das instituições não midiáticas. Na figura 4, por exemplo, a esfera institucional utiliza uma rede social para dar visibilidade a uma outra publicação através de um link. Já na figura 6, os atores sociais ultrapassam o limite da notícia, iniciando um processo de convocação através dos dispositivos midiáticos. A midiatização, dessa forma, redinamiza a organização social e modifica o processo de construção da realidade. 
0 elo organizador dos campos sociais agora está dissipado. Os espaços fronteiriços estão fluidos e 0 atravessamento dos campos sociais respeita outros movimentos. As estruturas perdem força para os processos, no caso os midiáticos. A sociedade em midiatização está atravessada por uma cultura de mídia. Para José Luiz Braga (2006, p. 2), nessa nova sociedade, os processos de interação midiatizada passaram a influenciar e absorver os demais. A midiatização figura como processo interacional de referência, pois tal realidade expande-se sobre a vida humana, alterando os processos sóciotécnico-discursivos. E se um processo é de referência, ele afeta a todos os indivíduos e instituições, ainda que em níveis diferentes. Sendo assim, atores sociais, instituições e mídia canônica, todos respeitam as lógicas midiáticas como base de suas interações. É o que foi constatado nos empíricos. Para a instituição Exército Brasileiro, a interação intermidiática é tão importante quanto a interação presencial com a população da Maré. A pacificação durou mais de um ano e, mesmo assim, não conhecemos de fato o trabalho do Exército nas comunidades. Se a midiatização é o processo interacional de referência, circular e interagir no terreno intermidiático é fator elementar no acolhimento do social. Em contrapartida, a população não se limita a questionar os militares nos portões da base na favela. Os textos produzidos (imagéticos ou não) nos revelam uma verdadeira ofensiva midiática contra o Exército. 0 que talvez nem corresponda ao sentimento dos moradores. Mas é 0 discurso que circula na esfera midiática o que permanece, que segue adiante, que é a referência.

Podemos enxergar esses conceitos na matriz elaborada por Jairo Ferreira (2007, p. 2), em que a midiatização se desenvolve a partir da inter-relação entre três polos: dispositivos midiáticos, processos sociais e processos de comunicação. Eles se afetam mutuamente e cada um pode interceder sobre as relações entre os demais. Quando a técnica está inserida no contexto de todos os indivíduos e instituições, as relações entre processos sociais e comunicacionais são cada vez mais atravessadas pelos processos acionados via dispositivos midiáticos. Em nosso caso, a matriz claramente se manifesta. 0 processo social da tentativa de pacificação do Complexo da Maré envolve interações entre diferentes atores e instituições. Nesse contexto, automaticamente se desenvolvem os processos de comunicação, que são alçados aos dispositivos midiáticos (quando não surgem nos próprios dispositivos) pela influência da midiatização. Aquela mesma tensão que encontramos nas ruas da Maré, entre militares e moradores, está reproduzida no Facebook, por exemplo. A mesma cautela que a tropa demonstra é confirmada pelo Exército nas redes sociais.

Pedro Gilberto Gomes (2013, p. 137) traz a última contribuição para nossa tentativa de sintetização do conceito de midiatização. Uma nova ambiência caracterizada pelo compartilhamento de experiências; um verdadeiro caldo cultural. Para o autor, essa perda da soberania do campo dos media como o superintendente das relações entre os campos sociais é um salto qualitativo. A sociedade em midiatização, funcionando sob a cultura de mídia, transforma a ambiência em uma grande zona de interfaces, onde a circulação acelerada supera a especialização. 0 caldo cultural se forma porque a produção de sentido está dividida, compartilhada. Como vimos em nosso caso, não há uma imagem do Exército formada de acordo com os critérios enunciativos da mídia canônica. As experiências, percepções e concepções dos atores individuais e das outras instituições estão circulando também. Com isso, temos diferentes imagens em construção, diferentes narrações sobre um mesmo acontecimento, diferentes sentidos em produção e uma nova realidade social.

Essa nova organização social está diretamente ligada a uma mudança no paradigma da comunicação. 0 modelo linear foi quebrado com a midiatização, pois os emissores e receptores agora convivem em condições simétricas. Aquele discurso dotado de legitimidade para ser aceito em todos os campos sociais já não existe, tal como observamos na heterogeneidade das imagens expostas como materialidades. A midiatização traz uma dinâmica de equivalência discursiva, em uma ambiência com fronteiras cada vez mais diluídas e espaços de convivência cada vez mais sobrepostos. Os novos lugares 
de fala, descentralizados, modificam inclusive as relações entre os meios e seus produtores/consumidores. Na ambiência interdiscursiva, os sentidos se descolam de seus produtores e receptores, ficando suscetíveis a desvios e novas apropriações. A midiatização, dessa forma, reconfigura as instâncias de emissão/produção e consumo/recepção. Voltando ao nosso caso, observamos que as três instâncias estão produzindo diferentes imagens, mas também estão consumindo, redirecionando. 0 conceito de midiatização aponta para uma realidade ainda mais complexa. As estratégias das três instâncias que descrevemos estão em contato no terreno intermidiático. Não podemos visualizar apenas os subconjuntos separadamente. As estratégias são distintas, mas as imagens produzidas estão em contínua relação. A midiatização é justamente esse desalinho, e suas pistas estão na transversalidade.

\section{A TRANSVERSALIDADE DAS IMAGENS EM CIRCULAÇÃO}

Para adentrarmos as questões da transversalidade entre produção e consumo e suas mútuas afetações, faz-se necessária uma recuperação do conceito de circulação sob a ótica da midiatização. As transformações nos regimes sócio-técnicodiscursivos levaram as relações entre atores sociais, instituições e mídia canônica a uma lógica de interfaces, como foi exposto acima. Nessa ambiência interdiscursiva, entre os fluxos transversais, tanto os desajustes como as articulações podem aparecer. A circulação, que por muito tempo foi entendida como uma simples zona ${ }^{6}$, agora é considerada um conceito central para a midiatização (Fausto Neto, 2010, p. 12).

Algumas características da circulação midiatizada, em que os dois polos (produção e recepção) convivem em simetria: 1) rupturas em algumas lógicas de produção e recepção (a instantaneidade do midiático canônico pode ser superada pelos atores sociais, por exemplo); 2) a quebra dos contratos por parte dos receptores (o discurso da mídia canônica já não é mais aceito por todos); 3) o interesse de um mesmo produtor/receptor por várias mídias (o institucional, por exemplo, além de fonte para a mídia canônica, inscreve seus discursos em outros dispositivos, o que demonstra que a circulação é essencialmente intra e intermidiática7); 4) a cogestão dos acontecimentos pelos incontáveis produtores/receptores (conforme estamos analisando, a narrativa da pacificação compartilhada pelas três instâncias). Por esses fatores, Fausto Neto (2013, p. 55) aponta: "a circulação desponta como um território que se transforma em lugar de embates de várias ordens, produzidos por campos e atores sociais". A midiatização faz com que a paisagem circulatória coloque em contato as instâncias de produção e recepção, ao mesmo tempo em que as estimula para movimentos segundo suas próprias dinâmicas. Isso leva à reflexão sobre a produção de sentido a partir de um feixe de relações. Produção e recepção em encontros e desencontros nessa rede de fluxos transversais, fazendo da pluralidade de lógicas uma realidade complexa que fomenta a produção de sentido.

Retomemos novamente a pergunta inicial: como se dá a construção da imagem do Exército Brasileiro na operação de pacificação do Complexo da Maré? Inferimos preliminarmente uma disputa intermidiática por produção de sentido. Ocorre que, nessa ambiência de fluxos transversais e afetações mútuas, estamos tratando também de uma coprodução imagética. Ainda que não respeitem as mesmas estratégias, as instâncias ora se aproximam, ora se estimulam, mesmo defendendo posições diferentes. 0 terreno da disputa é um lugar que abriga esse feixe de relações. Vejamos alguns movimentos de circulação que revelam como as instâncias realizam suas estratégias.

6 Fausto Neto (2010) faz interessante explicação sobre os vários estágios do estudo da circulação, desde sua concepção linear até à alta complexidade do momento atual. 7 Esta concepção de circulação como inter e intramidiática vem sendo abordada por Ferreira (2013) e também por Ana Paula da Rosa (2015). Refere-se à inscrição de materiais significantes em pluridispositivos midiáticos de modo intramidiático, ou seja, dentro de um único dispositivo ou em vários, produzindo fluxos, circularidades, interações. Envolve a construção do valor daquilo que circula. 
Figura 7

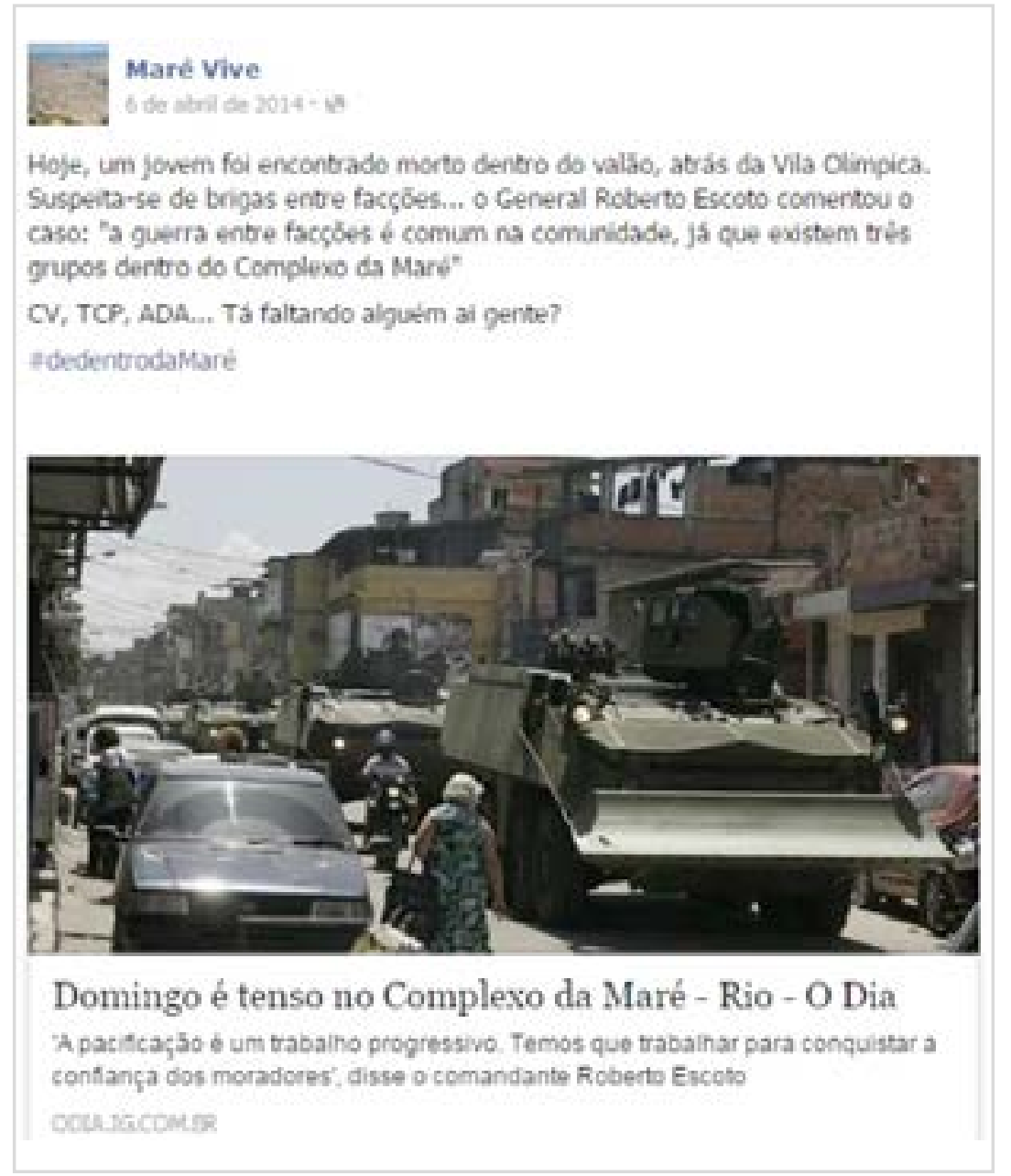

Fonte: https://pt-br.facebook.com/Marevive.

Figura 8

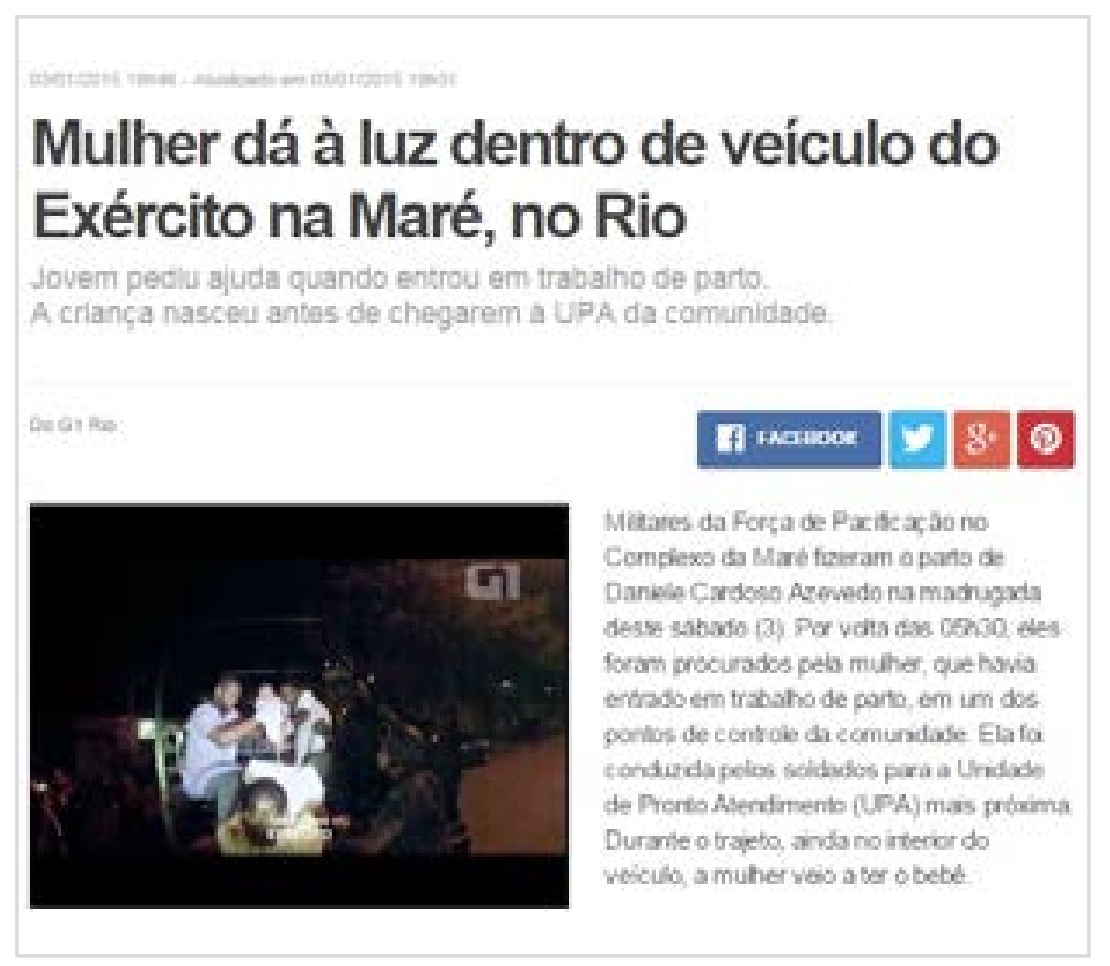

Fonte: http://g1.globo.com/rio-de-janeiro/noticia/2015/01/mulherda-luz-dentro-de-veiculo-do-exercito-na-mare-no-rio.html

A figura 7 é mais um registro da ocupação por parte dos atores sociais. Porém, diferentemente da imagem da figura 2, em que os próprios atores são os "registradores" (de fato) do acontecimento, na publicação da figura 7 eles estão se apropriando da 
imagem (e da matéria) de uma publicação da mídia canônica, no caso o portal de notícias 0 Dia. Esse movimento realizado pelos atores sociais engloba três dos níveis de circulação midiática descritos por Rosa (2015). 0 primeiro nível ${ }^{8}$ trata da atribuição de valor às imagens por parte das instituições jornalísticas, afetando as demais instituições e, no caso, os atores individuais. Ele é facilmente constatado, pois a maioria das imagens referentes ao caso da pacificação está ligada a blindados e militares fortemente armados ocupando as comunidades, em contraste a expressões de estranhamento dos cidadãos. Tais imagens convocam estruturas do social, na forma de imagens-totens (Rosa, 2012, p. 15). Vêm à tona experiências anteriores como as vividas em períodos de guerra ou ditadura, em um acionamento de estruturas estruturantes, que restringem novas interpretações. Trata-se de imagens autorreferenciais, pois embora estejamos vendo uma imagem de pacificação, o blindado sintetiza um outro lugar/contexto/fato, e todo esse repertório iconográfico coletivo é mobilizado pela escolha de determinadas imagens e exclusão de outras. As imagens-totens têm essa força, de símbolos, constituindo-se naquilo que representam.

O segundo nível corresponde ao acolhimento e à replicação de imagens por parte dos atores individuais em diferentes dispositivos, como verificamos na reinscrição da matéria do portal O Dia em uma página colaborativa do Facebook. Tal movimento demonstra um espelhamento, mas, mais do que isso, um acolhimento do valor e, portanto, uma possibilidade de permanência na circulação. 0 terceiro nível, denominado por Rosa (2015) de fagia social, diz respeito às novas camadas de sentido produzidas pelos atores individuais a partir da replicação das imagens construídas. Perceberemos esse movimento na figura 7 apenas se observarmos a matéria do portal 0 Dia na íntegra. No portal de notícias, por mais que seja apresentado o título de "Domingo é tenso no Complexo da Maré", o texto da matéria trabalha o sentido de uma ocupação tranquila por parte dos militares. Já na postagem do Facebook, os atores sociais não contemplam essa "tranquilidade" e reforçam o poder das facções criminosas. Nesses três níveis de circulação, ainda que o midiático canônico receba maior destaque por seu poder de atribuição de valor, a participação dos atores individuais é valorizada por conferir novos sentidos a essa mesma imagem. Dessa forma, as duas instâncias estão compondo a processualidade e dividindo a chancela daquilo que deve circular e, portanto, ser visível.

Mas a figura 8 ainda desvela mais um nível de circulação midiática, a fagia midiática (Rosa, 2015). Nesta imagem, a mídia canônica (portal de notícias G1) se apropria de um recurso audiovisual produzido pelo institucional (publicação do portal oficial e das redes sociais do Exército) para compor o registro de um fato. 0 movimento da fagia midiática assegura a afetação mútua entre as instâncias disputantes. Nessa imagem, podemos perceber como as instâncias de produção e recepção além de disputar, podem se aproximar, se articular e, até mesmo, trocar de lugar nessa ambiência tão complexa.

\section{CONSIDERAÇÕES FINAIS}

Observando esses movimentos de afetação mútua entre atores sociais, instituição e mídia canônica, inferimos que, mesmo com a constatação do emprego de estratégias de construção imagética heterogêneas por parte de tais instâncias, não podemos simplesmente aderir à pura aceitação da diferença. A disputa existe sim, pois, afinal, cada instância procura legitimar seu discurso, contar sua versão da história, revelar a imagem que percebe sobre o que está acontecendo. Mas a transversalidade das relações midiatizadas nos revela algo mais do que a simples agregação de diferentes imagens. Nesse

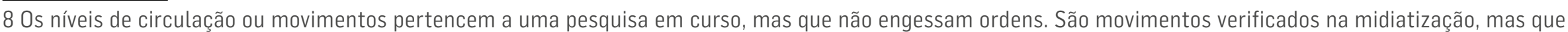

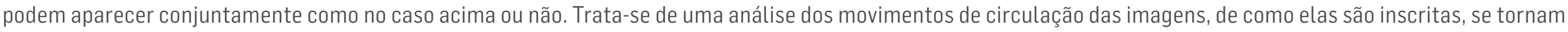
acessíveis e posteriormente passam a circular de fato, envolvendo a produção de sentido social.
} 


\section{ANO 13 • NÚMERO 24 • 1은. 2016 • ORGANICOM \\ ENTRE A DISPUTA E A COPRODUÇÃO: A IMAGEM DO EXÉRCITO BRASILEIRO NO COMPLEXO DA MARÉ}

terreno circulatório intermidiático, a imagem do Exército é construída em um jogo de articulação dessas diferenças, em uma coprodução que é fruto de interações que respeitam as lógicas da própria midiatização.

Nesse sentido, o resultado do problema apresentado no início do artigo, em relação a como se dá o processo de construção da imagem do Exército no Complexo da Maré, está ligado a uma abordagem da imagem institucional vinculada a uma nova realidade social, que a desvincula das concepções instrumentais do conceito (imagem projetada, técnica de gerenciamento de impressões, etc.). Aproximando-nos da processualidade do fenômeno da midiatização, a imagem institucional se revela como uma construção que envolve participação inter-relacionada de atores diversos, centrada em dois eixos: a heterogeneidade das visões do acontecimento e a transversalidade do que é inscrito na circulação. As imagens-produto circulantes se encontram e desencontram em mútua afetação, o que potencializa a (re)criação de imagens outras, que seguem novos fluxos adiante. 0 sucesso, a dúvida e o medo estão entre a disputa e a coprodução, vulneráveis aos desvios de uma rede complexa que potencializa e modifica o "fazer" imagens. Contudo, o fato de essa imagem institucional figurar como algo impossível de ser unicamente controlado por qualquer ator ou instituição não impede sua análise e interpretação, ou ainda o exercício de intervenções sobre ela.

\section{REFERÊNCIAS}

BRAGA, José Luiz. Mediatização como processo interacional de referência. In: ENCONTRO ANUAL DA COMPÓS, XV - GT Comunicação e Sociabilidade. Anais... Bauru, SP: Unesp/Compós, 2006.

FAUSTO NETO, Antonio. A circulação além das bordas. In: FAUSTO NETO, Antonio; VALDETARO, Sandra (orgs). Mediatización, sociedade y sentido: diálogos entre Brasil y Argentina. Rosario: Facultad de Ciencia Política y RRII, Universidad Nacional de Rosario, 2010.

Como as linguagens afetam e são afetadas na circulação? In: BRAGA, José Luiz et al (orgs.). Dez perguntas para a produção do conhecimento em comunicação. São Leopoldo, RS: Editora Unisinos, 2013.

Fragmentos de uma analítica da midiatização. Matrizes, São Paulo, n. 2, p. 89-105, abr. 2008.

FERREIRA, Jairo. Midiatização: dispositivos, processos sociais e de comunicação. E-Compós, Brasília, v. 10, p. 1-15, 2007.

FERREIRA, Jairo. Como a circulação direciona os dispositivos, indivíduos e instituições? In: BRAGA, José Luiz et al. (orgs.). Dez perguntas para a produção do conhecimento em comunicação. São Leopoldo, RS: Editora Unisinos, 2013.

GOMES, Pedro Gilberto. Como o processo de midiatização (um novo modo de ser no mundo) afeta as relações sociais? In: BRAGA, José Luiz et al. (orgs.). Dez perguntas para a produção do conhecimento em comunicação. São Leopoldo, RS: Editora Unisinos, 2013.

RODRIGUES, Adriano Duarte. Experiência, modernidade e campo dos media. In: SANTANA, R. N. Monteiro de (org.). Reflexões sobre o mundo contemporâneo. Rio de Janeiro: Revan; Teresina: Universidade Federal do Piauí, 2000.

ROSA, Ana Paula da. De reflexos a fagias: os níveis de circulação e apropriação midiática das imagens. In: CONGRESSO INTERNACIONAL DE MIDIATIZAÇÃO. Anais... Buenos Aires: 2015. (A ser publicado). 


\section{ANO 13 • NÚMERO 24 • 1은. 2016 - ORGANICOM \\ ENTRE A DISPUTA E A COPRODUÇÃO: A IMAGEM DO EXÉRCITO BRASILEIRO NO COMPLEXO DA MARÉ}

Imagens-totens: a fixação de símbolos nos processos de midiatização. São Leopoldo, RS: Unisinos, 2012. Tese (Doutorado em Ciências da Comunicação). Disponível em: <http://biblioteca.asav.org.br/vinculos/000003/0000033A.pdf>. Acesso em: 15 jan. 2016.

VERÓN, Eliseo. Esquema para el análisis de la mediatización. Diálogos de la Comunicación, n. 48, Lima, Felafacs, 1997.

Artigo recebido em 18.02.2016 e aprovado em 04.07.2016. 